\title{
A simple and efficient method for the long-term preservation of plant cell suspension cultures
}

\author{
Anne-Marie Boisson, Elisabeth Gout, Richard Bligny ${ }^{*}$ and Corinne Rivasseau*
}

\begin{abstract}
Background: The repeated weekly subculture of plant cell suspension is labour intensive and increases the risk of variation from parental cells lines. Most of the procedures to preserve cultures are based on controlled freezing/ thawing and storage in liquid nitrogen. However, cells viability after unfreezing is uncertain. The long-term storage and regeneration of plant cell cultures remains a priority.

Results: Sycamore (Acer pseudoplatanus) and Arabidopsis cell were preserved over six months as suspensions cultures in a phosphate-free nutrient medium at $5^{\circ} \mathrm{C}$. The cell recovery monitored via gas exchange measurements and metabolic profiling using in vitro and in vivo ${ }^{13} \mathrm{C}$ - and ${ }^{31} \mathrm{P}-\mathrm{NMR}$ took a couple of hours, and cell growth restarted without appreciable delay. No measurable cell death was observed.

Conclusion: We provide a simple method to preserve physiologically homogenous plant cell cultures without subculture over several months. The protocol based on the blockage of cell growth and low culture temperature is robust for heterotrophic and semi-autotrophic cells and should be adjustable to cell lines other than those utilised in this study. It requires no specialized equipment and is suitable for routine laboratory use.
\end{abstract}

Keywords: Plant cell suspension, Acer pseudoplatanus, Arabidopsis thaliana, cell preservation, in vitro and in vivo NMR spectroscopy, low temperature, phosphate starvation

\section{Background}

Suspension culture of isolated plant cells is an invaluable tool for providing the material for high-throughput studies such as metabolic analyses, production of secondary plant products, and herbicide discovery. It enables easy experimentation on physiologically and biochemically homogenous population of cells. Different methods for cultivating large quantities of plant cells in liquid nutrient medium (NM) have been described for a long time [1-4]. These methods are based on the subculture of cell suspensions having reached their growth plateau when most of the nutrients initially added to NM, particularly carbohydrates, are metabolised. It leads to more or less homogenous cell populations and usually induces a growth delay (lag phase) following subculture [5]. It has been shown that obtaining homogenous cell suspension cultures requires sophisticated apparatus such as chemostats that optimize NM and cell growth [6]. Alternatively, subcultures every one or two

\footnotetext{
*Correspondence: rbligny@cea.fr; corinne.rivasseau@cea.fr Commissariat à l'Energie Atomique, institut de Recherche en Technologies et Sciences pour le Vivant, Laboratoire de Physiologie Cellulaire Végétale, Unité Mixte de Recherche 5168 CNRS, UJF, INRA, CEA, F-38054 Grenoble, France
}

days also yields homogenous cell populations [7], but involve much handling and maintenance that is therefore difficult to perform over long periods of time.

For this reason, alternative procedures to preserve newly optimized cell suspension cultures, ideally for indefinite periods, have been proposed. Apart from the maintenance of cell callus on solid media which lead to appreciable delays to initiate homogenous cell suspension cultures, most of the procedures are based on controlled freezing/ thawing and storage in liquid nitrogen [8-12]. However, the viability of the cells after unfreezing is generally low and long lag phases before full recovery of cell culture growth are always mentioned by authors. The highest viability (up to 90\%) was observed by Menges and Murray [13] after cryopreservation of Arabidopsis and tobacco cells in the presence of DMSO and sorbitol. Nevertheless, even in this case, it takes at least one week for cells to recover normal post-thaw growth and full re-establishment, and there is a risk that preserved cell lines may differ from the original ones [14].

Here, we describe a procedure aiming at preserving higher plant cell populations in their suspension nutrient 
medium over several months, keeping them homogenous and ready to restart growth after their return to standard culture conditions. The main problem is that, in standard cultures, carbon substrates are consumed within less than two weeks. Afterwards autophagic process and cell death are observed $[15,16]$. In order to diminish the carbohydrate consumption by cells, cultures were carried out at low temperature in a first series of assays. Cultures were then carried out at low temperature in the absence of phosphate $(\mathrm{Pi})$ so as to induce the arrest of cell growth [17]. In order to validate this procedure, the cell's physiological and biochemical states were monitored both via the measurement of cell growth and gas exchange and by in vivo and in vitro metabolic profiling utilising ${ }^{31} \mathrm{P}$ - and ${ }^{13} \mathrm{C}-\mathrm{NMR}$ [18-20]. Indeed, NMR monitoring permits the detection of early signals of metabolic disruption related to carbon deprivation [21] leading to the expression of autophagy-related genes [22]. Heterotrophic sycamore (Acer pseudoplatanus L.) cells and semi-autotrophic Arabidopsis cells (Arabidopsis thaliana L., wild type, Columbia ecotype) were used to compare results obtained with nonchlorophylous cells of cambial origin to those obtained with illuminated chlorophylous cells of leaf parenchyma origin. It was expected that, due to photosynthesis activity, the cellular need for exogenous carbohydrate would be lower, thus permitting a reduction in NM renewal.

\section{Results and discussion}

Growth of sycamore and Arabidopsis suspension-cultured cells at $22^{\circ} \mathrm{C}$ and $5^{\circ} \mathrm{C}$

At $22^{\circ} \mathrm{C}$, the fresh weight (FW) of weekly subcultured sycamore cells increases exponentially with time, without a lag phase ([7] and Figure 1A). A plateau corresponding to a cell FW of $150 \pm 15 \mathrm{~g} \mathrm{l}^{-1}$ of culture is reached after two weeks. If cells are subcultured at this stage, a 2-d lag phase attributed to the exhaustion of sucrose supply and to the beginning of the related process of autophagy is observed. At $5^{\circ} \mathrm{C}$, the cell density doubling time is much longer: $10 \mathrm{~d}$ vs $2.5-2.7 \mathrm{~d}$ at $22^{\circ} \mathrm{C}$ (Figure 1B). Interestingly the $\mathrm{pH}$ of their NM, initially adjusted to 5.7 , increased progressively up to 7.1-7.3. This is probably due to the presence of nitrate as the only nitrogen source in Lamport's NM and to the lower emission of acidifying $\mathrm{CO}_{2}$, whereas it remains below 6.5 at $22^{\circ} \mathrm{C}$.

The growth of Arabidopsis cells cultivated under photomixotrophic conditions at $22^{\circ} \mathrm{C}$ showed a similar profile (Additional File 1A) and a plateau corresponding to a cell concentration of $200 \pm 20 \mathrm{mg} \mathrm{ml}^{-1}$ culture was reached within ca 10 days. Here too, lowering the temperature resulted in a marked decrease of cell culture growth rate (Additional File 1B). The cell density doubling time increased from 2.1-2.3 d to ca $8 \mathrm{~d}$. Cultures performed in Murashige and Skoog medium use ammonium and nitrate as a nitrogen source, leading the NM's pH to decrease progressively to ca. 5.0.

The growth rates of both types of cells incubated over one month at $5^{\circ} \mathrm{C}$ recovered standard values as soon as the culture temperature was set back to $22^{\circ} \mathrm{C}$ (Figure 1 and Additional File 1 arrows). Despite this extended period of very slow growth, no significant lag phase was observed before cell growth restarted at $22^{\circ} \mathrm{C}$, suggesting that the preservation of cells at low temperature did not substantially modify their physiological properties. To confirm this conclusion, measurements of $\mathrm{O}_{2}$-uptake by cells and NMRbased control of their metabolite profile were performed.

\section{$\mathrm{O}_{2}$-uptake at $22^{\circ} \mathrm{C}$ and $5^{\circ} \mathrm{C}$}

The $\mathrm{O}_{2}$ uptake rates of sycamore and Arabidopsis cells cultivated at $22^{\circ} \mathrm{C}$, harvested during the exponential phase of growth, and measured at $22^{\circ} \mathrm{C}$ in the dark, were $350 \pm$ 25 and $480 \pm 40 \mathrm{nmol} \mathrm{O}{ }_{2} \mathrm{~min}^{-1} \mathrm{~g}^{-1}$ cell FW, respectively (Table 1). In contrast, the $\mathrm{O}_{2}$ uptake rate of the same cells cultivated at $5^{\circ} \mathrm{C}$ for $20 \mathrm{~d}$, and measured at $5^{\circ} \mathrm{C}$ in the dark, was much lower, averaging $72 \pm 7$ and $105 \pm 10$ nmol $\mathrm{O}_{2} \mathrm{~min}^{-1} \mathrm{~g}^{-1}$ cell FW, respectively. Interestingly, the uncoupled rate of $\mathrm{O}_{2}$ consumption measured in the presence of $2 \mu \mathrm{M}$ FCCP showed a higher relative increase at low temperature. This increase was close to $60 \%$ at $22^{\circ} \mathrm{C}$ and reached $100 \%$ at $5^{\circ} \mathrm{C}$ in sycamore and Arabidopsis cells. This indicates that the decrease of the normal (coupled) cell respiration observed at low temperature was not caused by a limitation of substrate supply to mitochondria or by the intrinsic mitochondria oxidative functioning. It is more likely caused by the general decrease of cell metabolism activity and the correlated decrease of cell need for nucleotide triphosphates (NTP). Increasing the temperature to $22^{\circ} \mathrm{C}$ after a 20 -d incubation at $5^{\circ} \mathrm{C}$ led to the full recovery of coupled and uncoupled cell respiration within 10 minutes.

The illumination of Arabidopsis cells in the $\mathrm{O}_{2}$-electrode chamber decreased the $\mathrm{O}_{2}$-uptake by cells by ca $30 \%$ at $22^{\circ} \mathrm{C}$, probably due to the contribution of $\mathrm{O}_{2}$ generating photosynthesis activity (Table 1 ). Indeed, in the light, these chlorophyllous cells incorporate ${ }^{13} \mathrm{CO}_{2}$ into carbon metabolites [unpublished result; 23]. At $5^{\circ} \mathrm{C}$, illuminating Arabidopsis cells also decreased the $\mathrm{O}_{2}$ uptake (Table 1). In addition, this decrease was proportionally greater than that observed at $22^{\circ} \mathrm{C}$ suggesting that, at low temperature, the photosynthesis activity of illuminated Arabidopsis cells was affected less than their respiration. Nevertheless, in these semi-autotrophic cells, even at $5^{\circ} \mathrm{C}$, the $\mathrm{O}_{2}$ produced by photosynthesis never compensated for the $\mathrm{O}_{2}$ consumed by respiration.

Metabolite profile of cells cultivated at $22^{\circ} \mathrm{C}$ and $5^{\circ} \mathrm{C}$

The metabolic profiles of sycamore and Arabidopsis cells grown at $22^{\circ} \mathrm{C}$ and $5^{\circ} \mathrm{C}$ were analysed from 


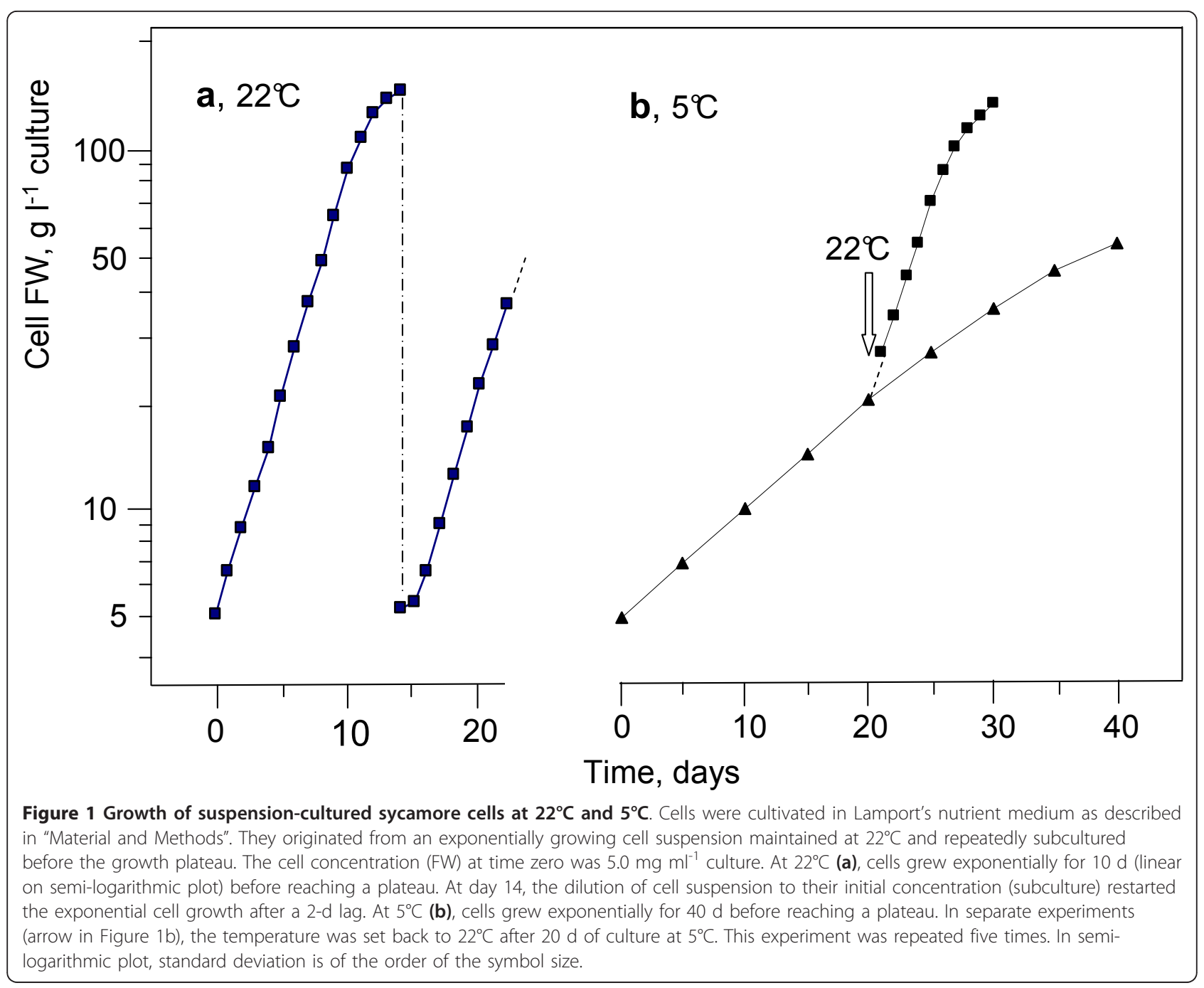

perchloric acid (PCA) extracts using ${ }^{13} \mathrm{C}$ - and ${ }^{31} \mathrm{P}$-NMR spectroscopy. ${ }^{13} \mathrm{C}$-NMR spectra show that lowering the temperature in sycamore cells induces significant change in their carbohydrate and organic acid stores (Figure 2). For example, sucrose decreased from 70-80 $\mu \mathrm{mol} \mathrm{g}^{-1}$ cell FW to $30-35 \mu \mathrm{mol} \mathrm{g}^{-1}$ cell FW, whereas citrate increased from 5.5-6.5 $\mu \mathrm{mol} \mathrm{g}^{-1}$ cell FW to $40-48 \mu \mathrm{mol} \mathrm{g}^{-1}$ cell FW and proline increased from 2.5-3.5 $\mathrm{mol} \mathrm{g}^{-1}$ cell FW to 8.5-9.5 $\mathrm{mol} \mathrm{g}^{-1}$ cell FW. Arabidopsis cells did not contain ${ }^{13} \mathrm{C}$-NMR-detectable carbohydrates, neither at $22^{\circ} \mathrm{C}$ nor at $5^{\circ} \mathrm{C}$ (Additional File 2). This means that their intracellular concentration was below $0.5 \mu \mathrm{mol} \mathrm{g}^{-1}$ cell FW, whatever the culture temperature. Concerning organic acids, glutamine concentration increased fourfold at low temperature, reaching 25-30 $\mu \mathrm{mol} \mathrm{g}^{-1}$ cell FW, and aspartate twofold, reaching 9-10 $\mu \mathrm{mol} \mathrm{g}^{-1}$ cell FW. On the contrary, citrate and malate, but not fumarate, decreased significantly. The very low level of soluble carbohydrates

Table $1 \mathrm{O}_{2}$-uptake by sycamore and Arabidopsis cells incubated at different temperatures

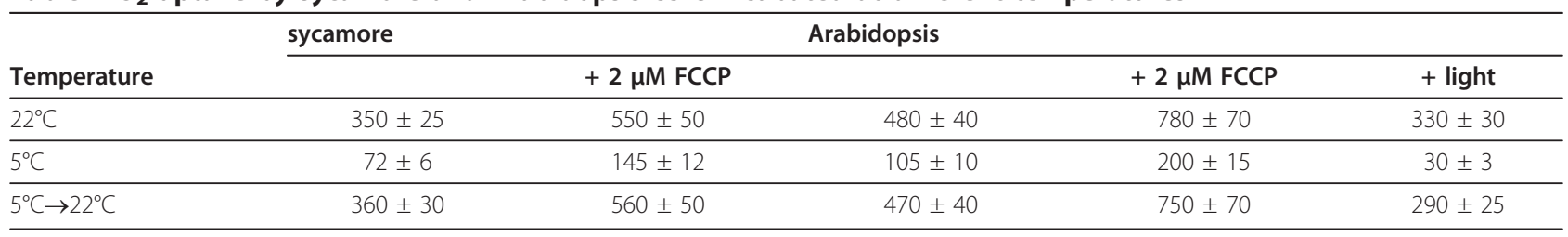

The $\mathrm{O}_{2}$-uptake by Sycamore and Arabidopsis cells harvested $5 \mathrm{~d}$ after subculture at $22^{\circ} \mathrm{C}$ and $20 \mathrm{~d}$ after subculture at $5^{\circ} \mathrm{C}$ was measured in their respective culture media at $22^{\circ} \mathrm{C}$ or $5^{\circ} \mathrm{C}$. In addition, the $\mathrm{O}_{2}$-uptake by cells cultivated for $20 \mathrm{~d}$ at $5^{\circ} \mathrm{C}$ was measured at $22^{\circ} \mathrm{C}$ after a 10 -min recovery $\left(5^{\circ} \mathrm{C} \rightarrow 22^{\circ} \mathrm{C}\right.$ ). $\mathrm{O}_{2}$-uptake rates were measured in the dark, except for Arabidopsis cells when specified (+ light), as indicated in "Material and Methods". They are expressed as nmol $\mathrm{O}_{2}$ consumed $\min ^{-1} \mathrm{~g}^{-1}$ cell FW. Values are means \pm SD $(n=5)$. FCCP, cyanide $p$-trifluoromethoxyphenylhydrazone. 


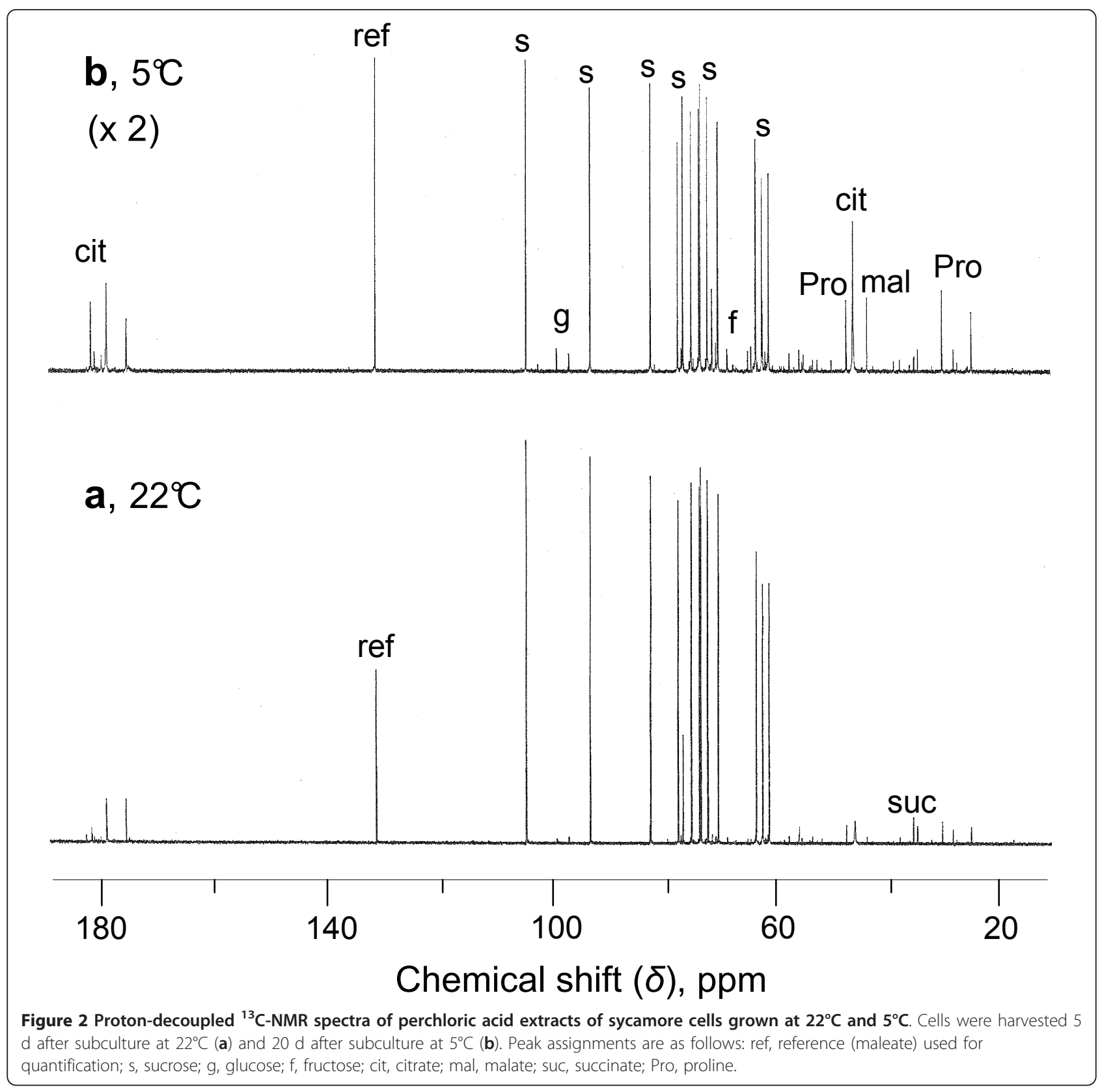

present in Arabidopsis cells and the low amount of starch [24] could contribute to why a dramatic fall of physiological activity and extensive transcriptomic responses are observed a few hours only after the onset of sugar deprivation leading to cell death within $24 \mathrm{~h}$ [25]. Indeed, in suspension-cultured Arabidopsis cells more than one third of the proteins content is degraded during the first $24 \mathrm{~h}$ of sucrose starvation [22], whereas it takes 2-3 d in sycamore cells $[26,27]$.

Increasing the temperature to $22^{\circ} \mathrm{C}$ after a one-month incubation at $5^{\circ} \mathrm{C}$ led to the recovery of standard ${ }^{13} \mathrm{C}$ NMR profiles for both types of cells within a couple of hours. For example, proline and glutamine which accumulate at low temperature and/or in the absence of $\mathrm{Pi}$ [28-30] were metabolised within a few hours. The accumulation of citrate and malate in sycamore cells could be attributed to the fact that the pH of Lamport's NM alkalizes with time [31]. The contrary was observed with Arabidopsis cells grown in Murashige and Skoog's NM which acidifies.

${ }^{31}$ P-NMR spectra (Figure 3 ) indicate that sycamore cells accumulate nearly twice as much hexoses phosphate and nucleotides at $5^{\circ} \mathrm{C}$ than at $22^{\circ} \mathrm{C}(0.70-0.80$ $\mu \mathrm{mol}$ glucose $6-\mathrm{P} \mathrm{g}^{-1}$ cell FW at $5^{\circ} \mathrm{C}$ vs $0.45-0.50 \mu \mathrm{mol}$ 


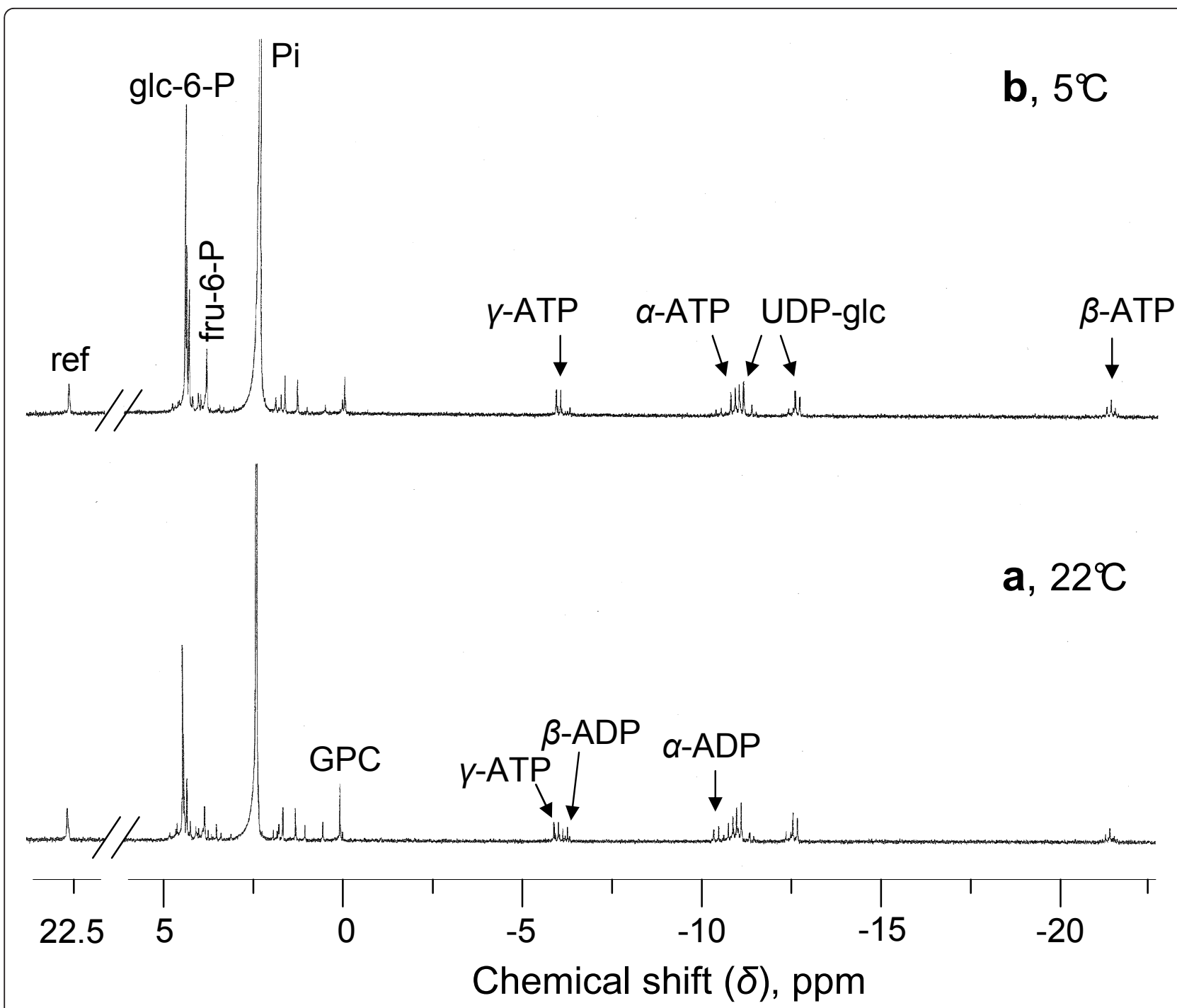

Figure 3 Proton-decoupled ${ }^{31} \mathrm{P}$-NMR spectra of perchloric acid extracts of sycamore cells grown at $22^{\circ} \mathrm{C}$ and $5^{\circ} \mathrm{C}$. Cells were harvested 5 $\mathrm{d}$ after subculture at $22^{\circ} \mathrm{C}$ (a) and $20 \mathrm{~d}$ after subculture at $5^{\circ} \mathrm{C}(\mathbf{b})$. Peak assignments are as follows: ref, reference (methylphosphonate) used for quantification; glc-6-P, glucose 6-phosphate; fru-6-P, fructose 6-P; Pi, inorganic phosphate; GPC, glycerophosphocholine; UDP-glc, uridine-5'diphosphate- $\alpha$-D-glucose.

at $22^{\circ} \mathrm{C}$, and $140-160 \mathrm{nmol} \mathrm{ATP} \mathrm{g}^{-1}$ cell FW at $5^{\circ} \mathrm{C}$ vs $80-90 \mathrm{nmol}$ at $22^{\circ} \mathrm{C}$ ). Similar results were obtained with Arabidopsis cells with the exception of glycerophosphoglycerol (GPG) accumulating at low temperature (Additional File 3). GPG is a phosphodiester involved in the metabolism of phosphatidylglycerol, the only abundant phospholipid in chloroplast membranes. Importantly, in both cell lines, neither P-choline nor asparagine accumulated, indicating the absence of cytosplasmic autophagy processes known to occur in cells lacking carbon supply $[15,16]$.

Increasing the temperature to $22^{\circ} \mathrm{C}$ after 20 days of incubation at $5^{\circ} \mathrm{C}$ led to the recovery of standard cell hexose-P and nucleotide concentrations within 10-15 minutes.

\section{Carbohydrate stores}

The consumption of sucrose in a nutrient medium is proportional to the number of cells growing in this medium and, consequently, it increases exponentially in accordance with the exponential growth of cell populations. At $22^{\circ} \mathrm{C}$, the rate of carbohydrate consumption by sycamore cells was $40-50 \mathrm{mg}$ sucrose $\mathrm{d}^{-1} \mathrm{~g}^{-1}$ cell FW (Figure 4 and Table 2). It took ca $10 \mathrm{~d}$ for the sucrose initially present in the $\mathrm{NM}$, where cells were subcultured, to be exhausted. At $5^{\circ} \mathrm{C}$, the rate of sucrose consumption per gram of cell FW was 4-5 times lower (Figure 4), and it took 5-6 weeks for the sucrose initially present in the culture medium to be exhausted. Similar rates of sucrose uptake by Arabidopsis cells cultivated in the light were measured. In the dark it was slightly 


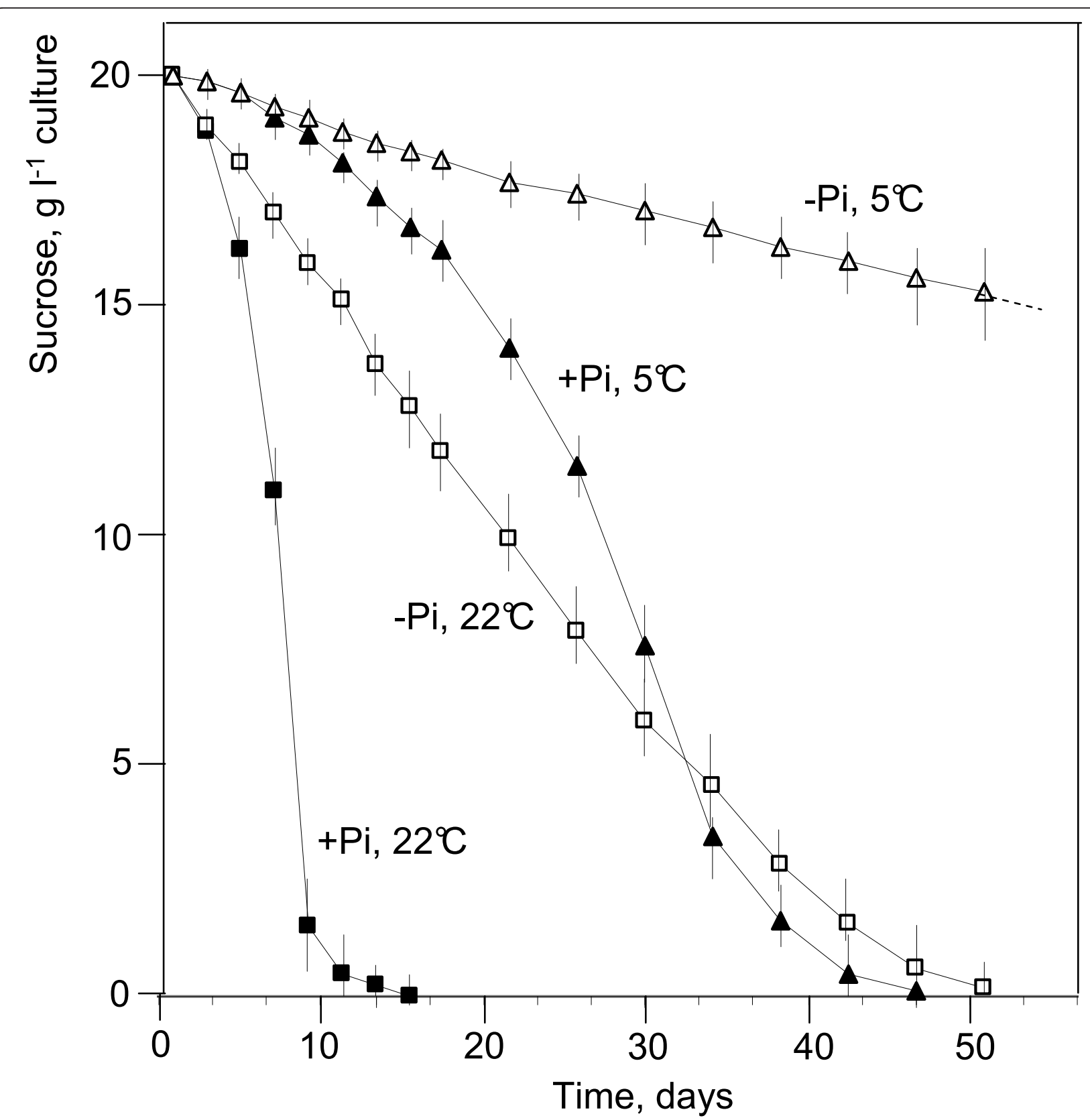

Figure 4 Temperature and phosphate effect on sucrose decrease in the nutrient medium of sycamore cell culture. Time course decrease of sucrose was measured in the nutrient medium of sycamore cell cultures at $22^{\circ} \mathrm{C}$ and $5^{\circ} \mathrm{C}$, in the presence or absence of inorganic phosphate (Pi). Cells were initially incubated for $5 \mathrm{~d}$ in Pi-supplied or Pi-free NM. The cell concentration (FW) at time zero was $20 \mathrm{mg} \mathrm{ml}^{-1}$ culture in Pi-supplied NM and $30 \mathrm{mg} \mathrm{ml}^{-1}$ culture in Pi-free NM. Sucrose was quantified as described in "Material and Methods". Values are given as means \pm SE $(n=3)$.

higher $\left(50-60 \mathrm{mg}\right.$ sucrose $\mathrm{d}^{-1} \mathrm{~g}^{-1}$ cell FW at $\left.22^{\circ} \mathrm{C}\right)$. At $5^{\circ}$ $\mathrm{C}$, the sucrose initially added in NM was consumed within only 4-5 weeks. This indicates that the contribution of photosynthesis to sugar supply nearly compensated for the slightly higher growth rate of this cell strain. After exhaustion of the sucrose present in NM, the intracellular stores of carbohydrates are consumed and cell autophagy starts [15]. For this reason, it was necessary to subculture cells grown at $5^{\circ} \mathrm{C}$ at least every 4-5 weeks.

Subculturing cell cultures monthly might nevertheless still look as an excessive constraint. Thus, the question was to determine whether it was possible to further diminish the consumption of carbohydrates by cells 
Table 2 Sucrose-uptake by sycamore cells incubated in Pi-supplied and Pi-deprived NM at $22^{\circ} \mathrm{C}$ and $5^{\circ} \mathrm{C}$

\begin{tabular}{lllll}
\hline & \multicolumn{2}{l}{ Pi-supplied NM } & \multicolumn{2}{l}{ Pi- starved NM } \\
\hline Temperature & $22^{\circ} \mathrm{C}$ & $5^{\circ} \mathrm{C}$ & $22^{\circ} \mathrm{C}$ & $5^{\circ} \mathrm{C}$ \\
\hline Sucrose uptake $\left(\mathrm{mg} \mathrm{d}^{-1} \mathrm{~g}^{-1}\right)$ & $51 \pm 5$ & $9.7 \pm 0.9$ & $17 \pm 1.5$ & $3.4 \pm 0.3$
\end{tabular}

Cells were initially incubated for $5 \mathrm{~d}$ at $22^{\circ} \mathrm{C}$ in either Pi-supplied or Pi-free Lamport's NM. At day 5 , incubation was pursued at $22^{\circ} \mathrm{C}$ or $5^{\circ} \mathrm{C}$ and sucroseuptake expressed as $\mathrm{mg} \mathrm{d}^{-1} \mathrm{~g}^{-1}$ cell FW was measured as indicated in

"Material and Methods". Values are means \pm SD $(n=5)$.

whilst at the same time keeping cell suspensions physiologically safe. Since nearly one half of incorporated sugar is consumed by respiration and the other half by different metabolic pathways involved in cell growth [32], we stopped cell growth before lowering the temperature. For this we incubated cells in a Pi-free NM.

\section{Cell culture at $5^{\circ} \mathrm{C}$ in Pi-starved media and recovery}

At $22^{\circ} \mathrm{C}$, provided sucrose is added regularly to NM, it is possible to keep cell cultures alive in a Pi-free nutrient medium for several months. After a few days, the cell concentrations of $\mathrm{Pi}$, phosphorylated intermediates of glycolysis, and nucleotides dramatically decrease [17,32], whereas the phospholipid/galactolipid ratio is reduced by ca. $70 \%$ $[33,34]$. Under these culture conditions, the growth of sycamore and Arabidopsis cells stops within one week (Figure 5 and Additional File 4). Afterwards, both the cell concentration and the rate of carbohydrate uptake from NM remained constant (Figure 4). Surprisingly, the cell respiration rate of $\mathrm{Pi}$-deprived cells is only $30 \%$ lower (Table 3) than that of cells cultivated in standard NM (Table 1). In addition, the uncoupled respiration rates of $\mathrm{P}$ - deprived and Pi-supplied cells were similar, indicating that Pi-starvation did not modify the maximum potential activity of mitochondria. After the addition of Pi to NM, cell respiration recovered to normal values within minutes and cell ${ }^{31} \mathrm{P}-\mathrm{NMR}$ spectra showed a normal profile within a couple of hours [17].

When the incubation temperature of Pi-deprived cells was dropped to $5^{\circ} \mathrm{C}$, a fivefold decrease of cell respiration was observed (Table 3), as mentioned above in the case of $\mathrm{Pi}$ supplied cells, and the sucrose uptake from the culture medium diminished accordingly (see Figure 4 for sycamore cells). The mean sucrose uptake by sycamore cells was close to $3.4 \mathrm{mg} \mathrm{d}^{-1} \mathrm{~g}^{-1}$ cell FW (Table 2). This suggests, since their culture medium initially contains $20 \mathrm{~g} \mathrm{l}^{-1}$ sucrose, that it should be possible to keep alive $20 \mathrm{~g}$ of cells incubated at $5^{\circ} \mathrm{C}$ in one litre of a Pi-free NM culture over ca 10 months without renewing the culture medium.

After adding Pi to NMs and returning the temperature to $22^{\circ} \mathrm{C}$, the cell respiration of cells stored during 6 months at $5^{\circ} \mathrm{C}$ in $\mathrm{Pi}$ free medium returned to standard values within minutes (Table 3 ). This suggests that cell suspensions remained physiologically homogenous after months of preservation at low temperature in Pi-free NMs. In particular, no appreciable cell death was measured. Accordingly, Figures 6 and Additional File 5 show examples of sycamore and Arabidopsis cell metabolite profile recovery after 6 months of incubation at $5^{\circ} \mathrm{C}$ in Pi-free NMs. At time zero, the concentration of cell's soluble P-compounds was close to the threshold for in vivo ${ }^{31} \mathrm{P}-\mathrm{NMR}$ detection of ca $20 \mathrm{nmol}$. Thirty minutes after the addition of phosphate in the perfusing NMs, cytoplasmic Pi (cyt-Pi), and NTP recovered standard values, rapidly followed by glucose 6-P and UDP-glucose, and one hour later by vacuolar Pi. After two hours, the in vivo ${ }^{31} \mathrm{P}-\mathrm{NMR}$ profiles of sycamore and Arabidopsis cells were close to those of standard cells. In fact, the time course recovery of the metabolite profile of Pi-starved cells incubated over 6 months at $5^{\circ} \mathrm{C}$ resembles that observed by Pratt et al. [17] for cells incubated 5 days in $\mathrm{Pi}$-free $\mathrm{NMs}$ at $22^{\circ} \mathrm{C}$. The analysis of in vivo spectra also indicated that the cytoplasmic $\mathrm{pH}$ of both types of cells, as measured from the chemical shift of cyt-Pi as soon as it was unambiguously identified (30 $\mathrm{min}$ ), remained close to 7.4. This suggests that the regulation of the cytoplasmic $\mathrm{pH}$ was maintained by Pi-starved cells incubated at low temperature, as is the case at $22^{\circ} \mathrm{C}$ [32]. In vivo ${ }^{13} \mathrm{C}$ NMR cell profiles of $\mathrm{Pi}$-starved cells cultivated at $5^{\circ} \mathrm{C}$ were comparable to those of corresponding Pi-supplied cells. Similarly, a full recovery was observed within a few hours: hexoses were metabolised as well as accumulated amino acids.

Finally, the growth rates of cells incubated at low temperature in Pi-free NM rapidly recovered to standard values after the return to standard culture conditions. In particular, no appreciable delay was noticed (Figure 5) and cells can be further normally subcultured. This confirms that the preservation of culture cells at low temperature in a Pi-free medium not permitting cell growth, and without the addition of growth inhibitors, did not generate longlasting physiological and metabolic changes. Importantly, in vitro and in vivo ${ }^{13} \mathrm{C}$ - and ${ }^{31} \mathrm{P}-\mathrm{NMR}$ analyses showed that the metabolic changes observed at low temperature in the absence of Pi in NM were rapidly reversed following the return to standard cell culture conditions. In addition, the absence of lag phase during the recovery of full cell respiration and growth rates suggests that the cell population remains physiologically homogenous during the preservation period.

The protocol for preserving plant cells without subculture over several months is described step-by-step in Additional file 6 .

\section{Conclusion}

The incubation of sycamore and Arabidopsis cells in a Pi-free nutrient medium at $5^{\circ} \mathrm{C}$ allowed the cell lines to stay alive for several months. This was due to the arrest 


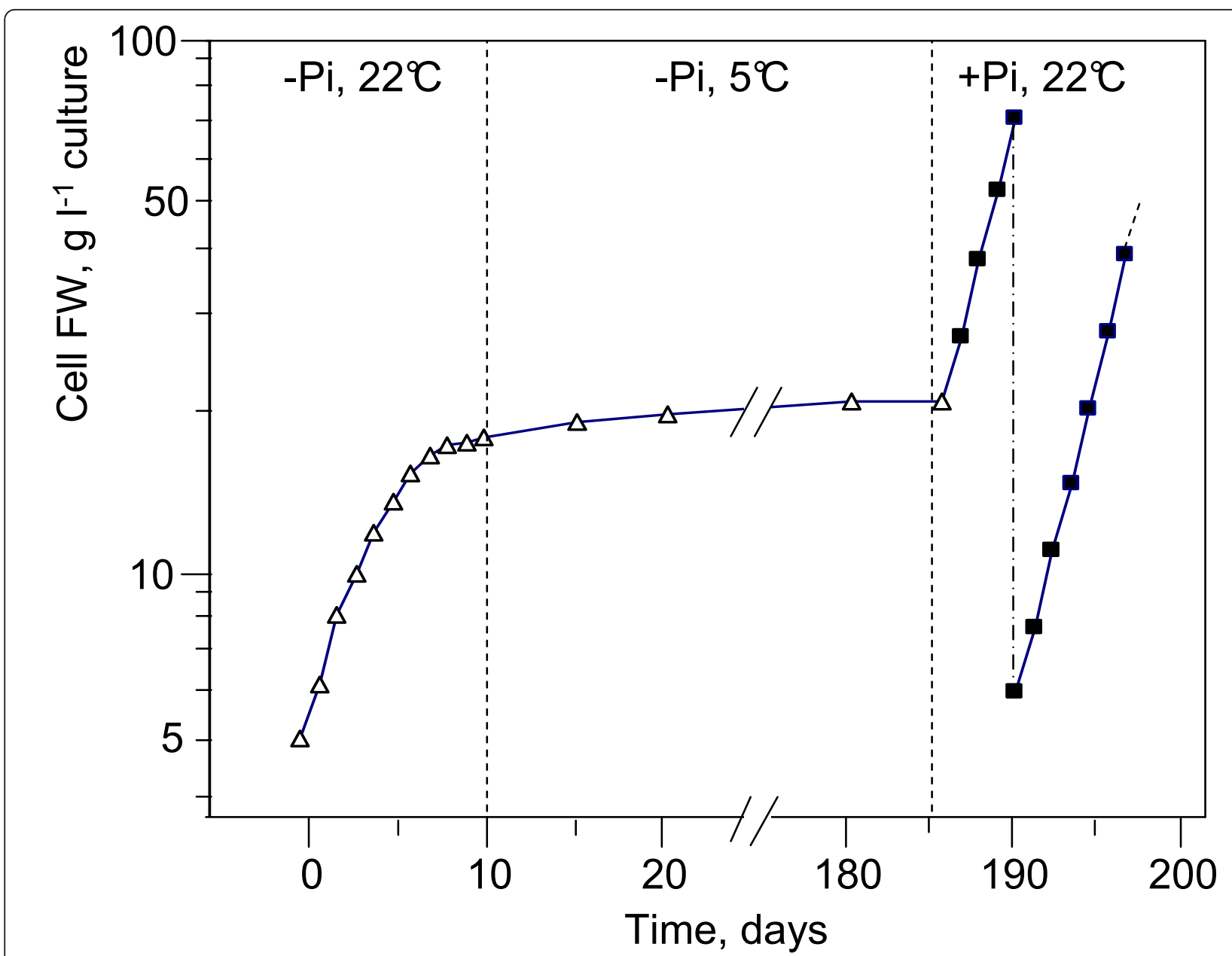

Figure 5 Growth of sycamore cells under different culture conditions. Growth of suspension-cultured sycamore cells was measured in a Pifree nutrient medium at $22^{\circ} \mathrm{C}$ followed by cell preservation at $5^{\circ} \mathrm{C}$, and recovery in a Pi-supplied medium at $22^{\circ} \mathrm{C}$. Cells were cultivated as described in "Material and Methods". They originated from an exponentially growing cell suspension repeatedly subcultured in Pi-supplied NM before the growth plateau. At time zero, cells were incubated at $5.0 \mathrm{mg} \mathrm{ml}^{-1}$ in Pi-free Lamport's NM at $22^{\circ} \mathrm{C}$. After a short period of exponential growth, a growth plateau corresponding to a cell concentration of only $20 \mathrm{mg}$ cell FW ml-1 culture was attained due to Pi starvation. At that stage, the temperature was set to $5^{\circ} \mathrm{C}$. Six months later preserved cells were incubated under standard culture conditions and subcultured (day 190). This experiment was repeated five times. In semi-logarithmic plot, standard deviation is of the order of the symbol size.

Table $3 \mathrm{O}_{2}$-uptake by sycamore and Arabidopsis cells incubated in Pi-free nutrient media at different temperatures

\begin{tabular}{|c|c|c|c|c|}
\hline \multirow[b]{2}{*}{ Temperature } & \multirow[t]{2}{*}{ sycamore } & \multicolumn{3}{|c|}{ Arabidopsis } \\
\hline & & $+2 \mu \mathrm{M}$ FCCP & & $+2 \mu \mathrm{M}$ FCCP \\
\hline $22^{\circ} \mathrm{C}$ & $250 \pm 25$ & $510 \pm 50$ & $320 \pm 30$ & $690 \pm 60$ \\
\hline $5^{\circ} \mathrm{C}$ & $59 \pm 6$ & $135 \pm 12$ & $70 \pm 7$ & $190 \pm 15$ \\
\hline $5^{\circ} \mathrm{C} \rightarrow 22^{\circ} \mathrm{C}$ & $370 \pm 30$ & $530 \pm 50$ & $470 \pm 40$ & $720 \pm 60$ \\
\hline
\end{tabular}

Sycamore and Arabidopsis cells were initially incubated for $5 \mathrm{~d}$ at $22^{\circ} \mathrm{C}$ in their respective NM devoid of $\mathrm{Pi}$ in order to stop cell growth. At day 5 , incubation was pursued at $22^{\circ} \mathrm{C}$ and $5^{\circ} \mathrm{C}$ in the same nutrient media. $\mathrm{O}_{2}$-uptake by Pi-deficient cells was measured after $5 \mathrm{~d}$ incubation at $22^{\circ} \mathrm{C}$ and 6 months incubation at $5^{\circ} \mathrm{C}$ In addition, the $\mathrm{O}_{2}$-uptake by cells incubated for 6 months at $5^{\circ} \mathrm{C}$ was measured at $22^{\circ} \mathrm{C}$ in standard Pi-supplied media after a 10 -min recovery $\left(5^{\circ} \mathrm{C} \rightarrow 22^{\circ} \mathrm{C}\right)$. All cells were incubated in the dark. $\mathrm{O}_{2}$-uptake rates measured as indicated in "Material and Methods" are expressed as nmol $\mathrm{O}_{2}$ consumed $\mathrm{min}^{-1} \mathrm{~g}^{-1}$ cell FW. Values are means $\pm \mathrm{SD}(n=5)$. FCCP, cyanide $p$-trifluoromethoxyphenylhydrazone. of cell growth resulting from Pi starvation, which was initiated 10 days before lowering the temperature, and to the large decrease of cell metabolic activity at low temperature as indicated by the drop of respiration. Importantly, no cell death was observed and cells recovered a normal physiological and biochemical activity without a long delay or lag period.

To summarize, the procedure of cell preservation described in this paper opens the possibility of storing plant cells lines for several months whilst retaining their capacity to restart growing homogenously and without delay. It can be performed easily and routinely, without requiring any specific equipment, freezing procedure, or addition of growth inhibitors. This method for the preservation of suspension cultured cell lines, with a 


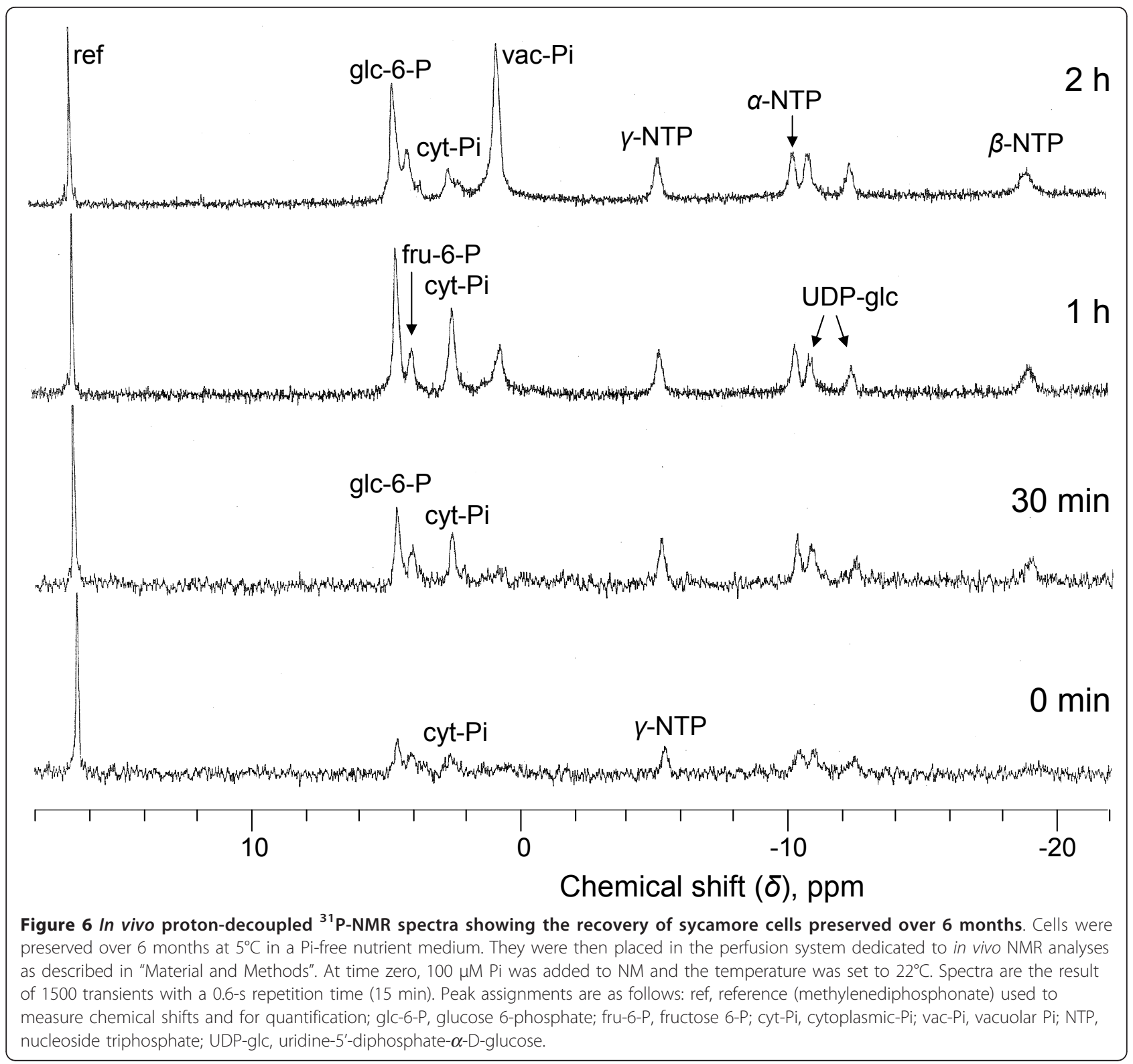

medium renewal every 6 months only, is now routinely used in our laboratory.

\section{Material and methods}

\section{Plant material and growth conditions}

Sycamore (Acer pseudoplatanus L.) and Arabidopsis (Arabidopsis thaliana L.) cells were respectively grown in Lamport [2] and Murashige and Skoog [35] nutrient media as described by Bligny and Leguay [36]. Both types of cells were aerated on orbital shakers monitored at $120 \mathrm{rpm}$ in either a cell culture room at $22^{\circ} \mathrm{C}$, or in a cold room at $5^{\circ} \mathrm{C}$. Arabidopsis cells received continuous illumination delivering $100 \mu \mathrm{mol} \mathrm{m} \mathrm{s}^{-2} \mathrm{~s}^{-1}$ photosynthetic photon flux density (PPFD) whatever the temperature.
Nutrient media contained $20 \mathrm{~g} \mathrm{l}^{-1}$ sucrose as carbohydrate source. At $22^{\circ} \mathrm{C}$, cell suspensions were subcultured each 7 days, i.e. before sucrose present in NM was exhausted, by adding $40 \mathrm{ml}$ of old cell culture to $200 \mathrm{ml}$ of fresh NM in 800-ml flasks in order to obtain an initial cell concentration of nearly 5-10 $\mathrm{mg} \mathrm{FW} \mathrm{ml}^{-1}$. At $5^{\circ} \mathrm{C}$ cells were subcultured when $90 \%$ of the initially added sucrose was consumed.

\section{Metabolomic analyses using NMR}

Analyses were performed either in vitro from perchloric acid (PCA) cell extracts or in vivo using freshly harvested cells. Extracts were prepared from 10-g (wet wt) cells quickly filtered, washed with pure water at $0^{\circ} \mathrm{C}$, 
and thrown into liquid nitrogen. Frozen samples with $0.7 \mathrm{ml}$ of $70 \%(\mathrm{v} / \mathrm{v})$ PCA were ground to a fine powder with a mortar and pestle at liquid nitrogen temperature. The frozen powder was then thawed at $0^{\circ} \mathrm{C}$ and the resulting thick suspension was centrifuged at $15,000 \mathrm{~g}$ for $10 \mathrm{~min}$ at $0^{\circ} \mathrm{C}$ to remove particulate matter. The supernatant was neutralised to $\mathrm{pH} 5.0$ with $2 \mathrm{M} \mathrm{KHCO}_{3}$ to precipitate PCA as $\mathrm{KClO}_{4}$, centrifuged at $15,000 \mathrm{~g}$ for $5 \mathrm{~min}$ and lyophilised. The freeze-dried material was dissolved in $2.0 \mathrm{ml}$ water containing $10 \%{ }^{2} \mathrm{H}_{2} \mathrm{O}$ for further NMR adjustment and $1 \mu \mathrm{M}$ sodium azide to avoid fermentation when unfrozen, and it was stored at $-20^{\circ} \mathrm{C}$.

In vitro NMR analyses were performed on a Bruker AMX 400 wide bore spectrometer (Bruker Instruments, Inc., Billerica, MA, USA) equipped with a $10-\mathrm{mm}$ multinuclear-probe. The probe was tuned at 100.6 and 162.0 $\mathrm{MHz}$ for ${ }^{13} \mathrm{C}$ - and ${ }^{31} \mathrm{P}-\mathrm{NMR}$, respectively. The deuterium resonance of ${ }^{2} \mathrm{H}_{2} \mathrm{O}$ was used as a lock signal. Spectra were recorded at $295 \mathrm{~K} .{ }^{13} \mathrm{C}$-NMR spectra were the result of 3600 transients with a 6 -s repetition time $(6 \mathrm{~h})$ recorded with $90^{\circ}$ pulses $(11 \mu \mathrm{s})$, a $20 \mathrm{kHz}$ spectral width, and a Waltz- $16{ }^{1} \mathrm{H}$ decoupling sequence with $2.5 \mathrm{~W}$ and $0.5 \mathrm{~W}$ during acquisition time and delay, respectively. Free induction decays were collected as 32,000 data points, zero-filled to 64,000 and processed with a $0.2-\mathrm{Hz}$ exponential line broadening. ${ }^{31} \mathrm{P}-\mathrm{NMR}$ spectra were the result of 1000 transients with a 3.6-s repetition time $(1 \mathrm{~h})$ recorded with $70^{\circ}$ pulses $(15 \mu \mathrm{s})$, a $8.2 \mathrm{kHz}$ spectral width, and a Waltz$16{ }^{1} \mathrm{H}$ decoupling sequence with $1 \mathrm{~W}$ during acquisition and $0.5 \mathrm{~W}$ during delay, respectively. Free induction decays were collected as 16,000 data points, zero-filled to 32,000 and processed with a $0.2-\mathrm{Hz}$ exponential line broadening.

For ${ }^{13} \mathrm{C}$-NMR analyses, $4 \mu \mathrm{mol}$ 1,2-cyclohexylenedinitrilotetraacetic acid (CDTA) was added to the PCA extract to chelate $\mathrm{Mn}^{2+}, 150 \mu \mathrm{mol}$ of maleate was added for calibration, and the $\mathrm{pH}$ was adjusted to 7.4. Spectra were referenced to the $-\mathrm{CH}=\mathrm{CH}$ - peak of maleate positioned at 131.4 ppm. For ${ }^{31} \mathrm{P}-\mathrm{NMR}$ analyses, all divalent cations were chelated by the addition of sufficient amounts of CDTA, $2 \mu \mathrm{mol}$ methylphosphonate was added for calibration, and the samples were buffered by addition of $150 \mu \mathrm{mol}$ Hepes at $\mathrm{pH}$ 7.4. Spectra were referenced to the peak of methylphosphonate positioned at $22.67 \mathrm{ppm}$. The identification of the peaks of resonance was done by comparing the spectra of standard solutions of known compounds at $\mathrm{pH} 7.4$ with that of the PCA extracts. The definitive assignments were made after running a series of spectra of the extracts spiked with authentic compounds, at different $\mathrm{pHs}$ to separate potentially overlapping peaks [18]. To accurately quantify compounds identified on spectra, the intensities of their different resonance peaks were referred to those of the reference compounds added to samples before grinding. Twenty seconds recycling time was used to obtain fully relaxed spectra. The integration function of the spectrometer was utilized to compare the intensity of resonance peaks.

In vivo NMR analyses were performed on the same spectrometer equipped with a $25-\mathrm{mm}$ multinuclear-probe. The deuterium resonance of ${ }^{2} \mathrm{H}_{2} \mathrm{O}$ was used as a lock signal. Cells (10 g FW) were placed in a $25-\mathrm{mm}$ NMR tube and oxygenated as described by Aubert et al. [18] with a perfusion flux of $20 \mathrm{ml} \mathrm{min}^{-1}$ sufficient for a perfect oxygenation of all cells at $22^{\circ} \mathrm{C}$. The 41 of perfusion NM contained the macro-nutrients (sucrose, $\mathrm{KNO}_{3}, \mathrm{NH}_{4} \mathrm{NO}_{3}$, $\mathrm{KCl}, \mathrm{Ca}\left[\mathrm{NO}_{3}\right]_{2}$, and $\mathrm{MgSO}_{4}$ ) normally present in $200 \mathrm{ml}$ of Lamport's or Murashige and Skoog's media, according to cell strains, which is sufficient for the growth of $10 \mathrm{~g}$ of cells over several days and limits decoupling-related temperature elevation at the level of analyzed cells. To further improve the signal-to-noise ratio, micro-nutrients, and in particular $\mathrm{Mn}^{2+}$, were not added to NM. The temperature of the perfusing NM was adjusted in a thermoregulated water bath outside the magnet.

${ }^{13} \mathrm{C}$-NMR spectra were acquired by accumulating 900 scans recorded with $90^{\circ}$ pulses $(70 \mu \mathrm{s})$ at 5.6-s intervals, a $20.7 \mathrm{kHz}$ spectral width, and a Waltz- $16{ }^{1} \mathrm{H}$ decoupling sequence with $4 \mathrm{~W}$ and $0.5 \mathrm{~W}$ during acquisition time and delay, respectively. Free induction decays were collected as 16,000 data points, zero-filled to 32,000 , and processed with a $2-\mathrm{Hz}$ exponential line broadening. Spectra were referenced to hexamethyldisiloxane contained in a capillary inserted inside the central outlet perfusion tube at $2.7 \mathrm{ppm} .{ }^{31} \mathrm{P}$-NMR spectra were acquired as described by Pratt et al. [17]. Spectra were referenced to methylenediphosphonate (MDP, pH 8.9) contained in the same capillary, at $17.38 \mathrm{ppm}$.

The identification of the resonance peaks was performed by comparing the in vivo spectra of perfused cells to those of PCA extracts prepared from these cells and adjusted at different $\mathrm{pHs}$, as described above. In vivo quantification was performed by comparing the spectra of analyzed cells with those of the extracts prepared from the same amount of cells, and using the MDP reference. The concentration of metabolites in the cytoplasm and in the vacuole were calculated as indicated in Pratt et al. [17]. Cytoplasmic and vacuolar $\mathrm{pH}$ (cyt- and vac-pH) was estimated from the chemical shift of the pools of $\mathrm{Pi}$ (cyt- and vac-Pi) present in these two compartments as described by Gout et al. [21].

\section{Other analytical methods}

The cell samples FW and the growth of cell suspensions were measured as described by Bligny and Leguay [36]. The oxygen uptake by cells was measured at $5^{\circ} \mathrm{C}$ and $22^{\circ} \mathrm{C}$ in their respective cell culture media. $\mathrm{O}_{2}$-uptake was monitored polarographically using a Clark-type 
oxygen-electrode (Hansatech Ltd King's Lynn, UK). 50 $\mathrm{mg}$ cell $(\mathrm{FW})$ was stirred in the $1 \mathrm{ml}$ measurement chamber filled with NM. The $\mathrm{O}_{2}$ concentration in the air-saturated $\mathrm{NM}$ was taken as $250 \mu \mathrm{M}$ at $22^{\circ} \mathrm{C}$ and 360 $\mu \mathrm{M}$ at $5^{\circ} \mathrm{C}$ according to Truesdale and Downing [37]. Uncoupled respiration was measured after adding $2 \mu \mathrm{M}$ cyanide $p$-trifluoromethoxyphenylhydrazone (FCCP). For photosynthesis measurements, Arabidopsis cells were illuminated with $500 \mu \mathrm{mol} \mathrm{m} \mathrm{m}^{-2} \mathrm{~s}^{-1}$ PPFD.

The sucrose present in NM was measured as described by Bergmeyer [38], using invertase, hexokinase, and glucose 6-P dehydrogenase, and by ${ }^{13} \mathrm{C}-\mathrm{NMR}$.

Neutral red was be used as a vital stain to detect the presence of dead cells in cultures.

When means \pm SD are given, the statistical Student's $t$-test was applied to the data with $P$ values $\leq 0.05$.

\section{Additional material}

Additional file 1: Growth of suspension-cultured lightened Arabidopsis cells at $22^{\circ} \mathrm{C}$ (a) and $5^{\circ} \mathrm{C}$ (b). Legend as in Figure 1.

Additional file 2: Proton-decoupled ${ }^{13} \mathrm{C}-\mathrm{NMR}$ spectra of perchloric acid extracts of Arabidopsis cells grown in the light at $22^{\circ} \mathrm{C}$ (a) and $5^{\circ} \mathbf{C}$ (b). Legend as in Figure 2; fum, fumarate; Asp, aspartate; Glu, glutamate; Gln, glutamine.

Additional file 3: Proton-decoupled ${ }^{31}$ P-NMR spectra of perchloric acid extracts of Arabidopsis cells grown in the light at $22^{\circ} \mathrm{C}$ (a) and $5^{\circ} \mathbf{C}$ (b). Legend as in Figure 3; GPG, glycerophosphoglycerol; spectra are the result of 250 transients

Additional file 4: Growth of suspension-cultured lightened Arabidopsis cells in a Pi-free nutrient medium at $22^{\circ} \mathrm{C}$ followed by cell preservation at $5^{\circ} \mathrm{C}$, and recovery in a Pi-supplied medium at $22^{\circ} \mathrm{C}$. Legend as in Figure 5.

Additional file 5: In vivo proton-decoupled ${ }^{31} \mathrm{P}-\mathrm{NMR}$ spectra of Arabidopsis cells. The recovery of preserved cell was followed in vivo after the return to standard perfusion conditions (Pi-supplied NM, 22 ${ }^{\circ} \mathrm{C}$ ) as indicated in the legend of Figure 6.

Additional file 6: Step-by-step description of the protocol for preserving plant cells without subculture over several months.

\section{List of abbreviations}

Pi: inorganic phosphate; PCA: perchloric acid; NM: nutrient medium; NMR: nuclear magnetic resonance.

\section{Acknowledgements}

We thank Dr James Tabony for reading the draft of the manuscript and for critical comments. We are indebted to Jean-Luc Le Bail for his assistance with NMR

\section{Authors' contributions}

$R B$ and $C R$ conceived the study and drafted the manuscript. A-M B and EG carried out the analysis and contributed to draft the manuscript. All authors approved the final manuscript.

\section{Competing interests}

The authors declare that they have no competing interests.

Received: 25 November 2011 Accepted: 30 January 2012 Published: 30 January 2012

\section{References}

1. Tulecke W, Nickel LG: Methods, problems and results of growing plant cells under submerged conditions. Transactions of New York Academy of Sciences 1960, 22:196-206.

2. Lamport DTA: Cell suspension cultures of higher plants: isolation and growth energetics. Experimental Cell Research 1964, 33:195-206.

3. Short KC, Brown EG, Street HE: Studies on the growth in culture of plant cells. V. Large-scale culture of Acer pseudoplatanus L. cell suspensions. Journal of Experimental Botany 1969, 20:572-578.

4. Wilson JB, King PJ, Street HE: Studies on the growth in culture of plant cells. XII. A versatile system for the large scale batch or continuous culture of plant cell suspensions. Journal of Experimental Botany 1971, 22:177-207.

5. Henshaw GG, Jha KK, Mehta AR, Shakeshaft DJ, Street HE: Studies on the growth in culture of plant cells. I. Growth patterns in batch propagated suspension cultures. Journal of Experimental Botany 1966, 17:362-377.

6. Monod J: La technique de culture continue. Théorie et applications. Annales de l'Institut Pasteur 1950, 79:390-410.

7. Bligny R: Growth of suspension-cultured Acer pseudoplatanus L. cells in automatic units of large volume. Plant Physiology 1977, 59:502-505.

8. Nag KK, Street HE: Freeze preservation of cultured plant cells. Part I. The pretreatment phase. Physiologia Plantarum 1975, 34:254-260.

9. Nag KK, Street HE: Freeze preservation of cultured plant cells. Part II. The freezing and thawing phase. Physiologia Plantarum 1975, 34:261-265.

10. Maddox AD, Gonsalves F, Shields R: Successful preservation of suspension-cultures of 3 Nicotiana species at the temperature of liquidnitrogen. Plant Science letters 1983, 28:157-162.

11. Jain $S$, Jain RK, Wu R: A simple and efficient procedure for cryopreservation of embryogenic cells of aromatic Indica rice varieties. Plant cell reports 1996, 15:712-717.

12. Kim SI, Choi HK, Son JS, Yun JH, Jang MS, Kim HR, Song JY, Kim JH, Choi HJ, Hong SS: Cryopreservation of Taxus chinensis suspension cell cultures. Cryo-letters 2001, 22:43-50.

13. Menges M, Murray JAH: Cryopreservation of transformed and wild-type Arabidopsis and tobacco cell suspension cultures. Plant Journal 2004, 37:635-644.

14. Zeliang PK, Pattanayak A, Inagrai B, Khongwir EA, Sarma BK: Fertile plant regeneration from cryopreserved calli of Oryza rufipogon Griff. and assessment of variation in the progeny of regenerated plants. Plant Cell Report 2010, 29:1423-1433.

15. Roby C, Martin J-B, Bligny R, Douce R: Biochemical changes during sucrose deprivation in higher plant cells. Phosphorus-31 nuclear magnetic resonance studies. Journal of Biological Chemistry 1987, 262:5000-5007.

16. Aubert S, Gout E, Bligny R, Mazars-Marty D, Barrieu F, Alabouvette J, Marty F, Douce R: Ultrastructural and biochemical characterization of autophagy in higher plant cells submitted to carbon deprivation; control by the supply of mitochondria with respiratory substrates. Journal of Cell Biology 1996, 133:1251-1263.

17. Pratt J, Boisson A-M, Gout E, Bligny R, Douce R, Aubert S: Phosphate (Pi) starvation effect on the cytosolic Pi concentration and $\mathrm{Pi}$ exchanges across the tonoplast in plant cells: an in vivo ${ }^{31} \mathrm{P}$-nuclear magnetic resonance study using methylphosphonate as Pi analog. Plant Physiology 2009, 151:1646-1657

18. Aubert S, Bligny R, Douce R: NMR studies of metabolism in cell suspensions and tissue cultures. In Nuclear Magnetic Resonance in Plant Physiology. Edited by: Shachar-Hill Y, Pfeffer P. Rockville, USA: American Society of Plant Physiologists; 1996:109-154.

19. Fan TW-M: Recent advances in profiling plant metabolites by multinuclear and multi-dimensional NMR. In Nuclear Magnetic Resonance in Plant Physiology. Edited by: Shachar-Hill Y, Pfeffer P. Rockville, USA: American Society of Plant Physiologists; 1996:181-254.

20. Krishnan P, Kruger NJ, Ratcliffe RG: Metabolite fingerprinting and profiling in plants using NMR. Journal of Experimental Botany 2005, 56:255-265.

21. Gout E, Bligny R, Douce R, Boisson A-M, Rivasseau C: Early response of plant cell to carbon deprivation: in vivo ${ }^{31} \mathrm{P}-\mathrm{NMR}$ spectroscopy shows a quasi-instantaneous disruption on cytosolic sugars, phosphorylated intermediates of energy metabolism, phosphate partitioning, and intracellular pHs. New Phytologist 2011, 189:135-147. 
22. Lundgren Rose T, Bonneau L, Der C, Marty-Mazars D, Marty F: Starvationinduced expression of autophagy-related genes in Arabidopsis. Biology of the Cell 2006, 98:53-67.

23. Chen W-P, Yang X-Y, Harms GL, Gray WM, Hegeman AD, Cohen JD: An automated growth enclosure for metabolic labeling of Arabidopsis thaliana with ${ }^{13} \mathrm{C}$-carbon dioxide - an in vivo labeling system for proteomics and metabolomics research. Proteome Science 2011, 9:9-22.

24. Williams TCR, Miguet L, Masakapalli SK, Kruger NJ, Sweetlove L, Ratcliffe RG: Metabolic network fluxes in heterotrophic Arabidopsis cells: stability of the flux distribution under different oxygenation conditions. Plant Physiology 2008, 148:704-718.

25. Contento AL, Kim S-J, Bassham DC: Transcriptome profiling of the response of Arabidopsis suspension culture cells to suc starvation. Plant Physiology 2004, 135:2330-2347.

26. Journet E-P, Bligny $R$, Douce R: Biochemical changes during sucrose deprivation in higher plant cells. Journal of Biochemical Chemistry 1986, 261:3193-3199.

27. Genix P, Bligny R, Martin J-B, Douce R: Transient accumulation of asparagine in sycamore cells after a long period of sucrose starvation. Plant Physiology 1990, 94:717-722.

28. Pollock CJ, ap Rees T: Effect of cold on glucose metabolism by callus and tubers of Solanum tuberosum. Phytochemistry 1975, 14:1903-1906.

29. Withers LA, King PJ: Proline: a novel cryoprotectant for the freeze preservation of cultured cells of Zea mays L. Plant Physiology 1979, 64:675-678.

30. Dorne A-J, Bligny R: Physiological adaptation to subantarctic climate by the Kerguelen cabbage, Pringlea antiscorbutica R. Br. Polar Biology 1993, 13:55-60.

31. Gout E, Bligny R, Pascal N, Douce R: ${ }^{13} \mathrm{C}$ nuclear magnetic resonance studies of malate and citrate synthesis and compartmentation in higher plant cells. Journal of Biological Chemistry 1993, 268:3986-3992.

32. Gout E, Boisson A-M, Aubert S, Douce R, Bligny R: Origin of the cytoplasmic $\mathrm{pH}$ changes during anaerobic stress in higher plant cells. Carbon-13 and phosphorus-31 nuclear magnetic resonance studies. Plant Physiology 2001, 125:912-925.

33. Jouhet J, Maréchal E, Baldan B, Bligny R, Joyard J, Block MA: Phosphate deprivation induces transfer of DGDG galactolipid from chloroplast to mitochondria. Journal of Cell Biology 2004, 167:863-874.

34. Misson J, Raghothama KG, Jain A, Jouhet J, Block MA, Bligny R, Ortet P, Creff A, Somerville S, Rolland N, Doumas P, Nacry P, Herrerra-Estrella L, Nussaume L, Thibaud M-C: A genome-wide transcriptional analysis using Arabidopsis thaliana Affymetrix gene chips determined plant responses to phosphate deprivation. Proceedings of the National Academy of Sciences USA 2005, 102:11934-11939.

35. Murashige T, Skoog F: A revised medium for rapid growth and bioassay with tobacco tissue cultures. Physiologia Plantarum 1962, 15:473-497.

36. Bligny R, Leguay J-J: Techniques of cell suspension culture. Methods in Enzymology 1987, 148:3-16.

37. Truesdale GA, Downing AL: Solubility of oxygen in water. Nature 1954, 173:1236.

38. Bergmeyer HU: In Methods of Enzymatic Analysis. Volume 3. New York: Academic press; 1974.

doi:10.1186/1746-4811-8-4

Cite this article as: Boisson et al: A simple and efficient method for the long-term preservation of plant cell suspension cultures. Plant Methods 2012 8:4.

\section{Submit your next manuscript to BioMed Central and take full advantage of:}

- Convenient online submission

- Thorough peer review

- No space constraints or color figure charges

- Immediate publication on acceptance

- Inclusion in PubMed, CAS, Scopus and Google Scholar

- Research which is freely available for redistribution 